\title{
The Mystical Spirit of Japan - Stefan Łubieński and Transnational Artistic Networks in 1920s Japan
}

\author{
Helena Čapková (iD) https://orcid.org/0000-0001-7547-5885 \\ Global Liberal Arts Faculty \\ Ritsumeikan University, Kyoto \\ e-mail: hcapkova@fc.ritsumei.ac.jp
}

\begin{abstract}
Stefan Łubieński (1893-1976), composer, fine artist, diplomat, spiritual seeker, and thinker, was a Polish nobleman, follower of Anthroposophy and author of such books as Ways to Spiritual Light and Man between Microcosm and Macrocosm. With his first wife, Zina Łubieńska, he resided in Japan in the first half of the 1920s. Although Łubieński published his autobiography and the names of the two Poles were mentioned at that time, the time they spent in Japan has not yet been analysed by scholars. This article is an attempt to unravel the Łubieńskis' life in Japan and show how it is placed in the context of Japanese culture in the 1920s. Furthermore, it will document the ways the Łubieńskis operated within the transnational network of Theosophists that spread among artists, foreign and Japanese alike, as a way to meet and exchange ideas. One of the circles the Łubieńskis joined, together with Noémi and Antonín Raymond, was the Garakutashū (en. "Circle for the Study of Odd Things and Junk"), a casual setting for open discussion about passion for collecting objects, hobbies, and a shared interest in Japanese arts such as woodblock printing, calligraphy, and ink painting. The transnational method used in this article foregrounds the importance of thinking through a lens highlighting transnational networks and enables us to recognize the Łubieńskis as a part of the Theosophical Society (TS), Garakutashu, and other networks of modern Japan.
\end{abstract}

Keywords: Stefan Łubieński, Modern Japan, modernism, Japan and Poland, japonisme, Anthroposophy, Theosophical Society, modern spirituality

Słowa kluczowe: Stefan Łubieński, nowoczesna Japonia, Japonia i Polska, japonizm, antropozofia, Towarzystwo Teozoficzne, nowoczesna duchowość

\section{Introduction}

Artists Stefan Łubieński and his wife Zina resided in Japan in the first half of the 1920s. Although Stefan published his autobiography and the names of the two Poles appear sporadically in contemporary writing of the time, their activities in Japan 
have remained unexplored by scholars until recently. ${ }^{1}$ This article aims to shed some light on Stefan Łubieński's life in Japan and to put it within the context, like a missing piece from a mosaic, of the cultural landscape of 1920s Japan. Furthermore, it will document the ways the Łubieńskis operated within the transnational network of Theosophists that spread among artists, foreign and Japanese alike, as a way to meet and exchange ideas.

Stefan Łubieński (1893-1976), composer, fine artist, diplomat, spiritual seeker and thinker, was a Polish nobleman whose life-long study of Anthroposophy inspired him to write numerous books, such as Ways to Spiritual Light and Man between Microcosm and Macrocosm ${ }^{2}$ which lay out his own vision of a human path. His curiosity to find a place of higher spirituality shaped his younger years and would lead him to Japan. However, it was his own spiritual exploration, anchored in his lived experiences and Rudolf Steiner's (1861-1925) philosophical ideas that determined his later life upon return to Europe. The quest for higher spirituality dominated his life, although he worked in various fields, including music teaching, translation, design, and diplomacy. Łubieński himself claimed that it was primarily the search for superior culture and arts that took him to Japan, where he and his wife, and collaborator, Zina eventually stayed for a number of years. ${ }^{3}$

The beginning of the Eubieńskis' journey to the East was in Paris. There, presumably through the expanding international occult networks, the couple encountered the likeminded Frenchman, Philippe Barbier Saint Hilaire (1894-1969), who worked as a chemical engineer, and whom Stefan referred to as their spiritual brother. ${ }^{4}$ Zina had studied dance with Raymond Duncan (1874-1966), brother of the American dancer Isadora Duncan, and was known as an accomplished singer. ${ }^{5}$ Duncan belonged to an influential group of innovators of modern dance and had developed a school centred around inspirations taken from ancient Greece, including the world of its drama and classical aesthetics.

The Lubieńskis and Philippe decided that they had to go to Japan, and they developed an idea to set up a workshop selling hand-woven tapestries. Some of the carpets would decorate the cultural centre for decorative art and music they were planning to open and use for artistic exchanges and spiritual encounters. In pursuit of this goal, they learned tapestry techniques in a basement in the evenings in Paris and believed that the novelty of the enterprise among the Japanese would ensure its success. ${ }^{6}$ Why the group settled on tapestry weaving as their primary revenue-generating activity has not yet been explained in detail. One may speculate that perhaps the trio

${ }^{1}$ S. Łubieński, Vor der Schwelle, Lebenserzählung eines polnischen Künstlers und Suchers (en. "Before the Threshold; Life story of one Polish Artist and Seeker"), Driebergen 1974. The book was illustrated with paintings by S. Wyspiański (1869-1907).

${ }^{2}$ S. Łubieński, M. Teernstra-Łubieński, Wegen naar geestelijk inzicht: het IK tussen microkosmos en macrokosmos (en. "Ways to Spiritual Light, Man between Microcosm and Macrocosm"), Deventer 1984. The English manuscript is ready for publishing, translated by Mila Teernstra-Lubienski.

${ }^{3}$ Idem, Vor der Schwelle..., op. cit., pp. 99-102.

${ }^{4}$ Ibidem, p. 100.

${ }^{5}$ Ibidem, p. 105.

${ }^{6}$ Ibidem, pp. 100-101. 
saw themselves as occult weavers, offspring of Arachne who would weave together the two cultures and spiritualities, the "Western" European and the "Eastern" Japanese through arts and culture.

\section{Departure for Japan}

Stefan Łubieński left, without Zina, for Japan from Marseille on 9 February 1921. In his autobiography Stefan divides the stay into two periods - from mid-March 1921 to the earthquake of 1 September 1923, and from the end of September 1923 to the end of September 1925 when he returned to Poland via Siberia and Moscow. His wife Zina arrived in Japan half a year later after Stefan. ${ }^{7}$ The Lubieńskis had previously married in Paris motivated by the opportunity to travel as a couple without offending contemporary moral standards and to secure visas to Japan more easily. By all accounts, they were spiritually close and experimented with Zina's psychic abilities. Some accounts characterise her as a medium, but regardless of one's views on such explanations she undoubtedly appears to have had an extremely powerful personality, which fact is supported by both published writings and unpublished correspondence by a number of well-known people who met her, including architect Frank Lloyd Wright (1867-1959), designer Noémi Raymond (1889-1980), and Philippe Barbier Saint Hilaire. ${ }^{8}$ Zina's mysterious and complex personality, as well as her refined artistic talents, may be partially rooted in her enigmatic family background. It appears she was likely the unwanted offspring of a secret and dangerous alliance amongst high-ranking Russian and Polish nobility. Her true lineage and identity were kept secret from her, and according to family history her true mother pretended to be her aunt. This burden followed her throughout her life, and Stefan describes the impact of this situation in detail in his autobiography. ${ }^{9}$

The beginning of the Łubieńskis' stay in Japan was marked by a struggle for money and support. Yet, despite all the difficulties, they were certain that they had reached a place of great artistic possibilities. Philippe Saint Hilaire was the anchor for the group because of his strong ties with the French Embassy in Tokyo and the fact that he could rely on their assistance, particularly in finding a suitable local workshop or factory for tapestry production. The ambassador, himself a playwright and committed Catholic mystic named Paul Claudel (1868-1955), became a good friend to all three spiritual seekers. Significant funds were needed for the weaving as, apparently,

${ }^{7}$ Ibidem, p. 100.

${ }^{8}$ F.L. Wright, An Autobiography, Petaluma 2005, p. 204; Correspondence between Noémi Raymond and Gurcharan Singh in 1922 (Antonín and Noemi Raymond archive, Architectural Archives at University of Pennsylvania); Correspondence between Noémi Raymond and Philippe Barbier Saint Hilaire I Pavitra, 1930s (Pavitra archive in Sri Auribindo Ashram Archives); see: Ph. Barbier Saint Hilaire, Itinéraire d'un enfant du siècle: correspondance de Pavitra avec son père: 1918-1954: de l'École polytechnique à l'ashram de Sri Aurobindo, de Paris à Pondichéry via le Japon et la Mongolie-Intérieure, Paris 2001.

${ }^{9}$ S. Łubieński, Vor der Schwelle..., op. cit., pp. 135-165. 
they were using wool imported from Australia. ${ }^{10}$ The loom had travelled with them from France in their baggage. The workshop they initially secured was only available to the collective for six months, but that was not where the difficulties ended. The weaving went slowly and did not sell well; nevertheless, they persisted.

They struggled, moving from house to house offered by Japanese and foreign friends alike, in Tokyo and Yokohama. Luckily soon, a sympathetic aristocratic count named Mizutani offered the use of a small house in the popular sea and spa resort of Atami, about $80 \mathrm{~km}$ southwest of Tokyo, one hour by train or overnight by ship. Łubieński wrote favourably of the small city of Atami, and finally, the newly settled collective produced its tapestries in white, dark grey and orange. ${ }^{11}$ However, the workshop operation was still insufficient to cover the expenses and the artists embarked on many side jobs. Stefan was drawing postcards and selling them, as well as photographs from WWI that were in demand. Zina, meanwhile, performed with Stefan for the local audiences in Atami. She sang Slavic folk songs and danced to classical music as well as to Stefan's improvisations (Fig. 1). The music composition did not much appeal to Stefan, however, as it seemed to him that these pursuits did not bring any money in. ${ }^{12}$

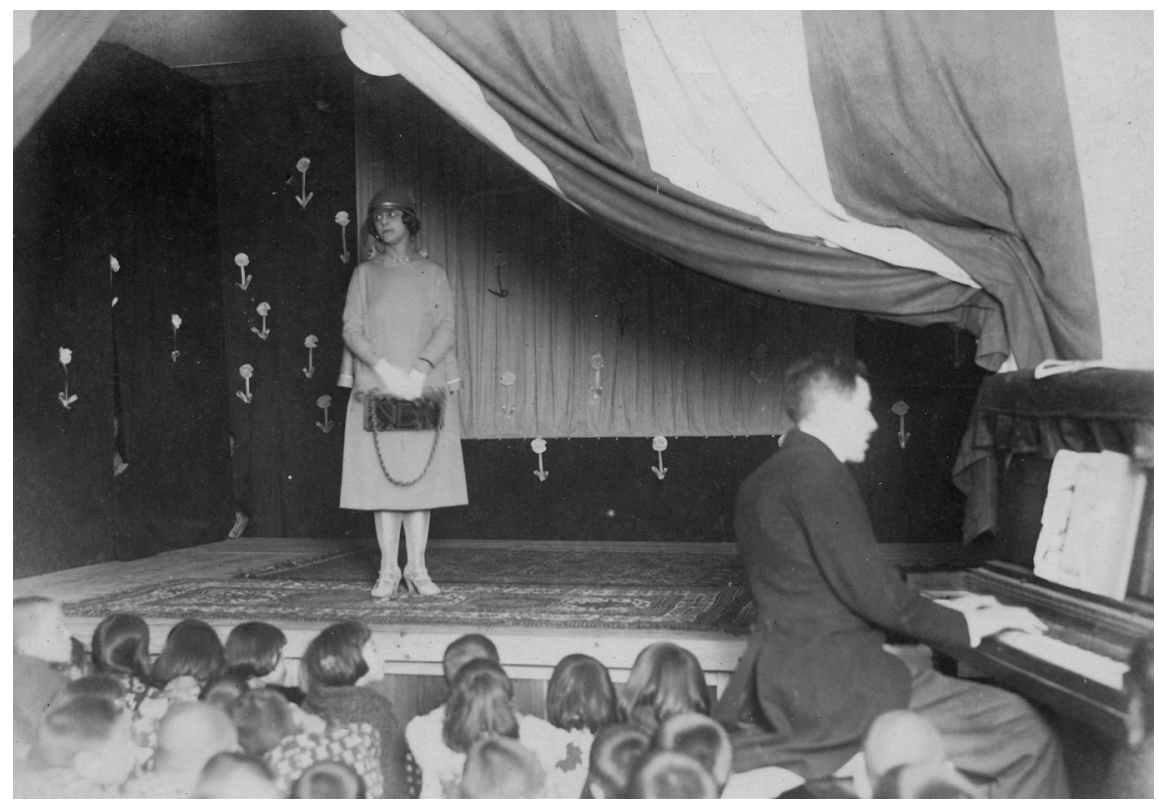

Fig. 1. Photograph from a recital by the Łubieńskis. Undated. Private collection.

\footnotetext{
${ }^{10}$ Ibidem, pp. 102-104.

${ }^{11}$ Ibidem, pp. 100-102.

12 Ibidem, p. 103.
} 


\section{Beginnings of artistic collaborations and friendships}

Stefan's autobiography includes some fascinating data from his diary. For example, he recollects finalising one small carpet rendering of the Pilgrims. On the way to sell it, it occurred to him that the motif could be part of a Noh drama, a form he drew on to create a new work, much later, after his return to Europe. ${ }^{13}$ Additionally, during his time in Japan, he used the opportunity to compare Japanese music to "Western" examples. These explorations led him to meet some Japanese composers, such as the renowned shakuhachi player Yoshida Seifu (1891-1950). ${ }^{14}$ Yoshida composed a piece, upon Łubieński's request, that is known as Adoration (1925). A quote from the CD sleeve:

When the Polish nobleman, Count Lubiensky, visited Japan in 1925, he commissioned this music for a ballet of his creation, inspired by ancient Greek sculpture, expressing the chaste devotions offered by the Athenian maidens to their gods. The music takes the following form: Introduction - The chaste devotion of the maidens - Joy that the gods will answer their prayer Terror that their prayers may not be answered - Confidence that their prayers, if sufficiently fervent, will surely be heard. ${ }^{15}$

These artistic creations may be expressions of the most profound and concrete impact of Łubieński's stay in Japan on his creative work, as he cooperated with Japanese artists from time to time.

Łubieński's network was growing, and he was becoming entwined with local Japanese circles exploring new kinds of spirituality, namely, the developing set of lodges of the Theosophical Society. The Łubieńskis became good friends with the Raymonds, Antonín and Noémi, a married couple of Czech-American designers, and with the French ambassador Claudel. From these diplomatic circles, it was only a small step to a network of successful Japanese industrialists who were inspired by and profited from their experiences abroad, and who could support initiatives by foreign artists in Japan. One of them was Antonín Raymond's client, Hoshi Hajime (1873-1952), who founded a pharmaceutical school in 1922 to expand his pharmaceutical empire and commissioned the young Raymond to build the campus. Hoshi was exactly the type of worldly modern Japanese man to be the perfect host and client for the young foreigners who not only wanted to explore Japan, but also had entrepreneurial ideas. Hoshi himself was a Columbia University graduate who had had a successful career in journalism in the US and Japan, before he chose to set up his own company, aiming to introduce modern over-the-counter drugs to Japan. ${ }^{16}$ The monumental, concrete building Raymond designed to act as the auditorium for

${ }^{13}$ Ibidem, pp. 157-161.

14 The surname/name order is used for Japanese names in this article. This follows Japanese standard.

${ }^{15}$ Y. Seifu, Koto Music of Japan - Music for Japanese Instruments, "Compositions of Yoshida Seifu," Toshiba Everclear - TM 5060, Track 1 Inori, https://www.komuso.com/albums/albums.pl?album=1039 [access: 6.01.2020].

${ }^{16}$ J.M. Jennings, The Opium Empire: Japanese Imperialism and Drug Trafficking in Asia, 1895 1945, Westport, CT 1997, p. 42. 
the school gained him great acclaim. Furthermore, Hoshi's company functioned as a significant networking space, in particular the gallery that hosted several exhibitions highlighting foreign artists' work in Japan on one floor of his trendy pharmaceutical shop. One more connection between Hoshi and Łubieński was established when Philippe Saint Hilaire became an employee of the Hoshi company. Saint Hilaire was very active in theosophical circles in early 1920s Tokyo. However, as noted by Łubieński, Saint Hilaire's view of life and career was changing and he soon went to Tibet, in 1924, and then through Theosophical circles to Puducherry, to begin to work with Sri Aurobindo Ghose. ${ }^{17}$

\section{Encounter with Hani Motoko and Jiyū Gakuen}

After some difficult times, the dream seemed to be coming true - the art centre was established, allowing Zina to teach dance in the style of Raymond Duncan. The centre featured recitation that followed teaching by Rudolf Steiner and performances of Ancient Egyptian hymns and "temple-mysteries." Stefan consulted with a member of Rabindranath Tagore's school who visited Japan and noted that the Indian visitor also hoped to have a centre that would be able to host tea ceremonies and teach Tao, Shinto ritual, Noh drama and Zen. These activities would support the idea they shared that art is a journey to the spiritual. ${ }^{18}$ Unfortunately, not much more is known about the activities in the art centre.

Parallel to their own activities, however, the Łubieńskis lectured at Jiyū Gakuen (en. "Free College"), a progressive school for girls founded by Christian activist Hani Motoko in Ikebukuro, Tokyo. Jiyū Gakuen can be cast as another busy transnational artistic intersection that was frequented by all the artists mentioned so far, and in this way, it was not unlike the Hoshi company. The first and main building of the Jiyū Gakuen school, now used only for special events under the label Myonichikan (en. "Palace of Tomorrow"), was designed by one of the key figures of 20th century architecture, Frank Lloyd Wright, in 1921. Wright had also been an important mentor to Antonín Raymond.

Although Łubieński claimed to have regularly lectured at Jiyū Gakuen, the school's archive only confirmed the couple's engagement on a more temporary and irregular basis. The school's newsletter noted that the Count and Countess Łubieński visited the school in the company of Endō Arata (1889-1951) an architect very closely involved in the architecture of the campus, the Hanis, and F.L. Wright, on 29 May 1923 (Fig. 2). They performed traditional Polish songs and Ancient Greek dances. During a performance by the school's Art Club in the Tokyo Imperial Hotel on 25 July, one class performed the play Cinderella, under the direction of the Countess. The performance was seen as a great success (Figs. 3 and 4). ${ }^{19}$

${ }_{17}$ S. Łubieński, Vor der Schwelle..., p. 156.

18 Ibidem, p. 108.

${ }_{19}$ Jiyū Gakuen no Rekishi 1 Zōshigaya jidai (en. History of Jiyū Gakuen 1 Zōshigaya period), Tokyo 1985, pp. 99-100. 
Fig. 2. Count and Countess Łubieński's visit to the Jiyū Gakuen on 29 May 1923, welcomed by the founders the Hanis and guided by the architect Endo Arata. Photo published in the article by Sagara Chieko, Tuesday Visitors, "Fujin no Tomo," 1923, vol. 7 , no. 1, p. 91.

Fig. 3. Zina Łubieńska in front of the Jiyū Gakuen Ikebukuro campus, undated photograph (1923), private collection.
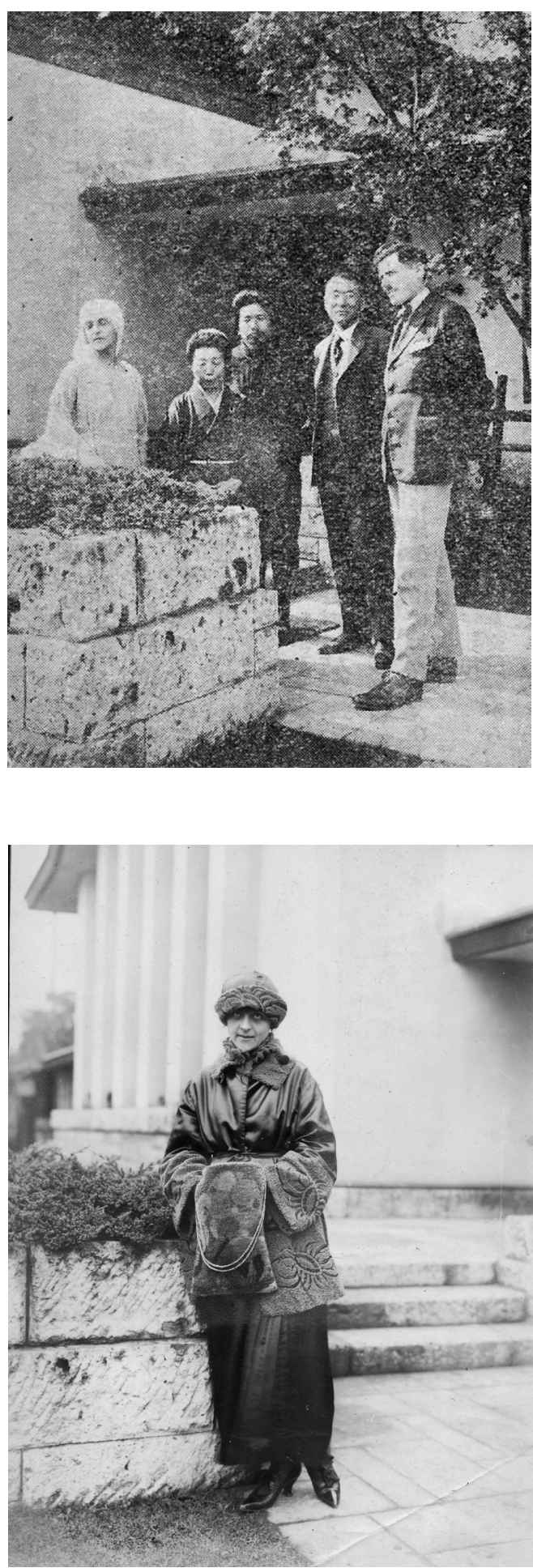


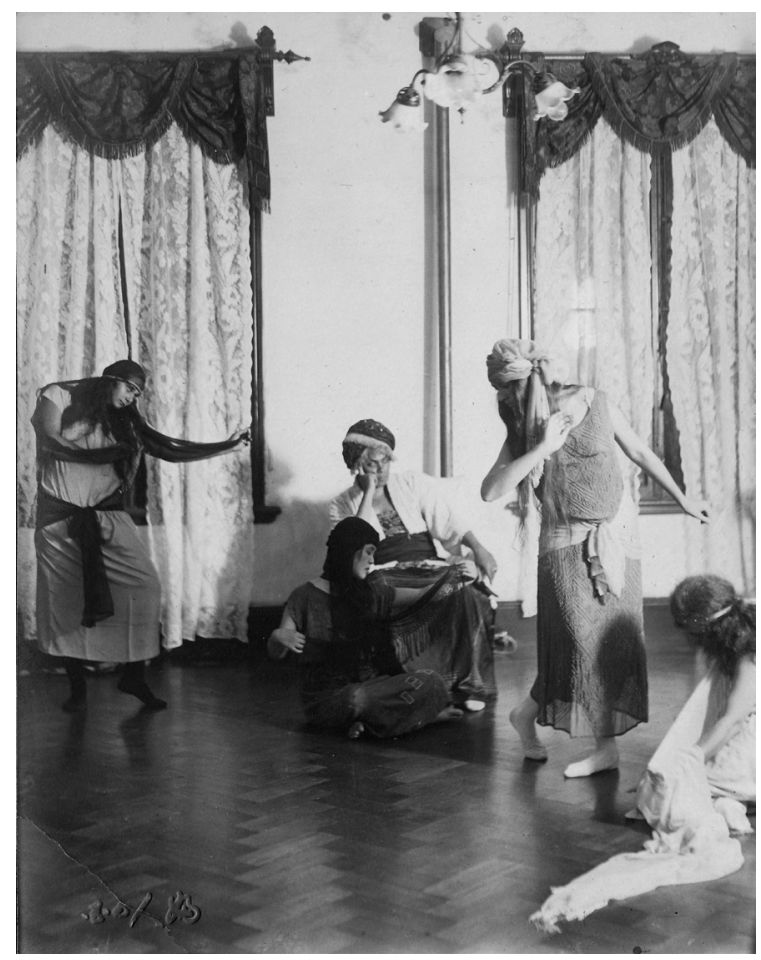

Fig. 4. Zina Łubieńska with the Jiyū Gakuen students rehearsing Cinderella, photo undated (1923), private collection.

A note in the school chronicle is echoed by a longer article in the popular magazine "Fujin no tomo" (en. "Wife's Friend") that further noted that Countess Łubieński spoke fluent Japanese. The article reported that the couple discussed issues related to progressive education as promoted by the school, comparing it with schools they were familiar with in France, Germany and Switzerland, and other Japanese schools they had already visited. They were very positive about Hani's educational practice and stated that they wished to introduce a greater focus on fostering the spiritual in what they saw as more materially oriented times. ${ }^{20}$

\section{Horikoshi-Łubieński Werkstätte and Shiseidō Gallery exhibition}

According to a story told by Stefan, he once visited Baron Kondo to sell a carpet. The Baron did not want to buy the carpet as the price was too high, but Łubieński got to visit a luxurious Japanese residence. He saw many beautiful carpets in the house and understood that to sell them was indeed a possibility if one had appropriate promotion. Baron Kondo put him in touch with a director of the large department store Mitsukoshi in Tokyo, who agreed to exhibit Łubieński's carpets for free. However, Łubieński again struggled with organising a big enough workshop and securing the

${ }^{20}$ Ch. Sagara, Tuesday Visitors, "Fujin no Tomo," 1923, vol. 7, no. 1, pp. 91-93. 
wool to produce the larger numbers of carpets needed to satisfy the capacity of the department store's storerooms. Instead, he built a workshop in Atami and focused on painting. New opportunities opened again when Stefan met an established architect named Horikoshi Saburo (1886-1972), who, as Łubieński says, became his friend and opened a new window into the mysteries of Japan to him. ${ }^{21}$ They met at a carpet exhibition at the Mitsukoshi department store and started a partnership together with Saint Hilaire in Horikoshi's architectural office, where Łubieński had begun working as a quality controller. This was the beginning of the Horikoshi-Łubieński Werkstätte. Soon they started producing upholstery for furniture in the French style as well as handbags, collars and other accessories. Łubieński wrote in his autobiography about the workshop operation and noted that the clover leaf logo was becoming recognized and fashionable. Some carpets were also designed for Horikoshi's houses. The popularity of the studio was boosted when the Empress ordered some of their products (furniture, art works) that were then highlighted in related magazines and design journals. As a result of this exposure, Stefan was asked to design a logo for the famous drink known as Kalpis. ${ }^{22}$ This collaboration between Łubieński and Horikoshi is relatively unknown and ripe for further exploration. Moreover, research on Horikoshi himself is very limited. Apart from a few mentions about his books, his skills have escaped the attention of architecture history scholars. We know that he worked for the major construction and development company Shimizu, and published books about Western-style architecture built in the late 19th century, at the beginning of the Meiji Era. After WWII, he became a leading figure at Kogakuin University in Tokyo.

In April 1923, the prestigious Shiseidō Gallery in Tokyo opened the exhibition Pōrando Bijutsu Seisakuten (en. "Exhibition of Polish Art”), displaying the spiritually charged artwork of Zina and Stefan Łubieński. This was probably the high point of their artistic visibility, and it built on their earlier energetic networking and a growing number of sales which drew on personal contacts. Among the works in the exhibition were the woodblock prints Power that created the World, Resurrection, and Female Ghost. ${ }^{23}$ The plans in Japan were developing extremely well, but it all was to change dramatically with the tragic event of the Great Kanto Earthquake on 1 September $1923 .^{24}$ The destruction brought by the quake was massive and many offices and warehouse in Akasaka were burnt down. The Werkstätte design products were destroyed, and many clients were impoverished. As a result, and after much contemplation, Łubieński resigned from the workshop and left everything to Horikoshi. Łubieński went on taking a multitude of jobs: he was a stenographer in an American trading company, taught Polish and Polish literature in Waseda University as an external lecturer, and also opened a small music school. Gradually, a following of young fine artists coalesced around him. At this time, Łubieński was approached by a Polonist, translator, and professor of literature at Waseda University, Kato Asadori,

${ }^{21}$ S. Łubieński, Vor der Schwelle..., op. cit., pp. 107-109.

22 Ibidem.

${ }_{23}$ Shiseidō Gyararī shichijūgonenshi: 1919-1994, H. Tomiyama (ed.), Tōkyō, 1995, pp. 253-254.

${ }^{24}$ S. Łubieński, Vor der Schwelle..., op. cit., p. 109. 
who was in the process of translating The Peasant (1924) by the Nobel-winning author Władysław Stanisław Reymont (1867-1925). Kato was planning to translate the four volumes of the book from English, although with Łubieński's assistance he contacted Reymont directly and in collaboration the team of three translated the work from the original Polish version.

\section{Leaving Japan and the book Between the East and the West}

Eventually, Zina secretly left Stefan and departed from Japan as well. Apparently, she left a note that she planned to disappear in the Swiss Alps, but instead she married another man, Baron Bout, with whom she lived in Holland, Egypt and later in Indonesia. Stefan searched for Zina, ${ }^{25}$ but when these efforts failed, he returned to Poland to embark on a diplomatic career in Holland, where he established a new family.

Łubieński went back to Poland via Siberia, and in 1927 he published the book Między Wschodem a Zachodem: Japonja na straży Azji: (Dusza mistyczna Nipponu) (en. "Between the East and the West: Japan as a Guardian of Asia: (Mystical Spirit of Japan)"), through which he intended to provide a contemporary perspective on Japan, its history, and culture. ${ }^{26}$

Between the East and the West offers a subjective perspective on Japan. Łubieński elaborates on music and analyses works of the composer Yamada Kōsaku (18861965) and his interpretations of Tchaikovsky and Beethoven. In the text devoted to reflections on spirituality, he introduces some examples from modern and recent Japanese history, such as the activities of the utopian thinker, writer, and founder of the pivotal literary journal Shirakabaha (en. "White Birch") Mushakoji Saneatsu (1885-1976). In 1918 Saneatsu established and was involved in leading the founding of a brotherhood with 150 members, based on humanitarian, vegetarian and pacifist principles, called Atarashikimura (en. "New Village"). The brotherhood celebrated five celebrations a year: New Year, Buddha's birthday, and the births of Jesus Christ, August Rodin and Tolstoy. ${ }^{27}$ Lubieński found the selection peculiar. In his book Łubieński touches on issues of literature, language, economy, and ancient and recent history, amongst others. Several times he quotes Okakura Kakuzo (1862-1913) and his notorious publication Book of Tea, which introduced and reinforced a whole array of stereotypes we still have to this day. In the conclusion, Łubieński states that the East and the West need to exist in equilibrium.

Later in Poland, Łubieński went on to work as a founding member of Krakow's conservatoire and then in the foreign service in Scotland and Holland. Zina visited him in Amsterdam many years later, probably in 1939, only to vanish again. Traces of her reappear in Indonesia in the 1940s. According to a witness, Zina was captured

${ }^{25}$ Ibidem, pp. 173-175.

${ }^{26}$ S. Łubieński, Między Wschodem a Zachodem: Japonja na straży Azji. Dusza mistyczna Nipponu, Warszawa 1927.

${ }^{27}$ Idem, Vor der Schwelle..., op. cit., p. 109. 
by the Japanese army and became a prisoner of war. In the camp she was involved in nursing other prisoners and later died there herself. ${ }^{28}$

During this time Stefan was persistently exploring Anthroposophical teaching and lectured annually at the September Esoteric Congress in Berlin. He published widely about esoteric mysticism. In his final years he became the leading member of a cultural centre, similar to the one he already envisaged building in Japan, in Kraybeek, Driebergen, where people received advice or help with their personal struggles and could enjoy lectures and concerts. He died as a respected Polish mystic, in Driebergen in Holland in 1976.

\section{Theosophy and Japan in the interwar period}

Theosophy and Japan in the interwar period has been a seldom explored area of study, and one of its leading figures at that time was an American named Beatrice Erskine Lane Suzuki (1878-1939). Not much is known about her, and Adele Algeo's article Beatrice Lane Suzuki and Theosopy in Japan published in the magazine Theosophical History in 2005 remains the key source of knowledge. Beatrice married the prolific thinker and successful promoter of Zen outside Japan, Suzuki Daisetsu (1870-1966) in 1911 in Yokohama, at which time she became a Japanese citizen. The couple spent much of their married life in Japan, teaching at various universities, publishing an English-language quarterly, The Eastern Buddhist, and interpreting Buddhism for the West through their many translations. There is no evidence that either of the Suzukis were Theosophists before they joined the Tokyo International Lodge in 1920, the year the lodge was formed. Doctor James H. Cousins was a founder of the Lodge and spent a year in Japan in 1919-1920 as a professor of modern English poetry at Keio University in Tokyo. In a letter dated 15 February 1920, Cousins wrote to the international TS headquarters in Adyar, India about the Lodge's inauguration with eleven members: five Japanese and six international members from America, Korea, Greece, and India. In a subsequent letter dated 30 October 1924 to the headquarters from the secretary of Mahayana Lodge in Kyoto, Beatrice Suzuki suggested that the Tokyo International Lodge was defunct and should return the charter.

Two Theosophist lodges existed simultaneously in Japan at this time: Mahayana in Kyoto and Orpheus in Tokyo. Orpheus Lodge was formed by its leader Philippe B. Saint Hilaire in May 1924. The founding charter was also signed by Stefan Łubieński, which makes him one of the founding members of Orpheus Lodge. In his book, however, Łubieński claimed that these were Anthroposophical circles and not associated with the TS. ${ }^{29}$ Saint Hilaire left Japan in the summer of 1924 (?) and was only loosely involved with the TS until he immersed himself in the teachings of integral yoga, associated with the guru Sri Aurobindo. Unexpectedly, in the summer of 1925, Saint Hilaire briefly returned to Tokyo, stayed with Łubieński and planned

${ }^{28}$ Information about the later life of Zina Łubienska was shared with the author during an interview on 23 December 2015 with Stefan Łubienski’s daughter, Mrs Adola McWilliam.

29 S. Łubieński, Vor der Schwelle..., op. cit., p. 161. 
to go to the TS convention in Adyar in December. ${ }^{30}$ During this time, 1924-1925, Łubieński stayed with another TS member, Countess Metaxa. ${ }^{31}$

A key figure in the TS movement, Madame Ina Metaxa was a Russian of Greek heritage and a refugee from Ukraine. She had been born Countess Kapnist in Greece, but marriage to her Russian husband, a lawyer, brought her to live on his estate in Russia. After the revolution, as aristocrats and Czarist supporters, the Countess and her husband were driven out of the country and sought refuge in the US and subsequently in Japan. ${ }^{32}$ Metaxa herself was an avid writer and political commentator, publishing extensively about feminism and art.

\section{Difficulties in spreading Theosophy in Japan}

In November 1928, in her last letter to the headquarters of the TS in Adyar, Beatrice wrote of the difficulties of spreading Theosophy in Japan. In this letter she provides what could be seen as a rather fitting description of the spiritual and intellectual affinity many other Theosophists, including the Raymonds, felt towards the Japanese:

It seems difficult for Theosophy to make much growth here just for this reason that it is so similar in its teachings to Buddhism. There seems to be a general idea, especially among Theosophists, that the Japanese are not a spiritual people and do not care for spiritual things. In my opinion this idea is entirely wrong. I consider the Japanese very spiritual; all that is best in their culture is based upon religion. No one could pass through this period of the Emperor's coronation without feeling how near the spiritual world is to the Japanese. But with regard to Theosophy, Theosophy comes not as something new but as a variant of their own Buddhist teaching and for this reason they are slow to come to it. The appeal of Universal Brotherhood is the note that must be struck by Theosophists for the Japanese. It is just the same too in regard to the Order of the Star. Their own great teachers like Kobo Daishi and others stand still too close to theirs in time and they feel that they have not yet fully absorbed the teachings of these great ones, and therefore they do not feel the call to look elsewhere. In my opinion it is not because of their unspirituality that they fail to do so but on account of their strong religious feeling for their own religious leaders. Personally, I should like to have a larger membership for I am deeply interested in the Society, but at the same time I appreciate the reasons why it is more difficult than it is in Western countries. ${ }^{33}$

Prior to her death in 1939, the activities of Beatrice Suzuki enjoyed support from foreign members of the TS, including artists such as Noémi Raymond. We know that Beatrice and Noémi were friends in the early 1930s, a result of research conducted in Noémi's personal library at her farm in New Hope, Pennsylvania. The author found in her library an inscribed copy of Beatrice Suzuki's Buddhism and

${ }^{30} \mathrm{Ph}$. Barbier Saint Hilaire, Itinéraire d'un enfant du siècle: de l'école polytechnique à l'Ashram de Sri Aurobindo, Paris 2001, pp. 117-126.

${ }_{31}$ S. Łubieński, Vor der Schwelle..., op. cit., p.161.

32 I. Kapnist, What Can Be Done to Save Russia Quickly?, “The Sun,” June 30, 1918, http://chroniclingamerica.loc.gov/lccn/sn83030431/1918-06-30/ed-1/seq-47/ [access: 22.02.2017].

33 A.S. Algeo, Beatrice Lane Suzuki and Theosophy in Japan, "Theosophical History" 2005, vol. 11, no. 3, pp. 3-16. 
the Practical Life (Kyoto 1933), which is understood to indicate their connection. Łubieński's friend, architect Antonín Raymond, who established his reputation in Japan through his collaboration with F.L. Wright on the Imperial Hotel in Tokyo, was a prime example of a networker who exploited every opportunity provided by his status and membership in various societies in Japan to arrange collaborations and projects, and to learn more about Japanese culture. Raymond's wife Noémi was an outstanding painter and graphic designer who, whilst in Japan, was also a crucial professional member of Raymond's architectural office. As early as 1919, she had joined the New York circle of the Theosophical Society and commenced a lifelong study of esoteric thought and religions. ${ }^{34}$ Her interest in spirituality, philosophy and religion led her to join circles of people with similar interests in Japan, such as Paul Claudel, the Indian potter Gurcharan Singh and the Lubieńskis (Fig 5). Unlike Antonín, Noémi learned Japanese and perhaps this allowed for a more profound, or at least different, understanding of Japan and the Japanese than that of her husband. Correspondence in relation to Noemi's search for spiritual fulfilment is found in letters she exchanged with Philippe Saint Hilaire, later known as Pavitra. Noémi's correspondence with Pavitra started in 1927 and lasted many decades. Unlike him, Noemi continued exploring Theosophy.

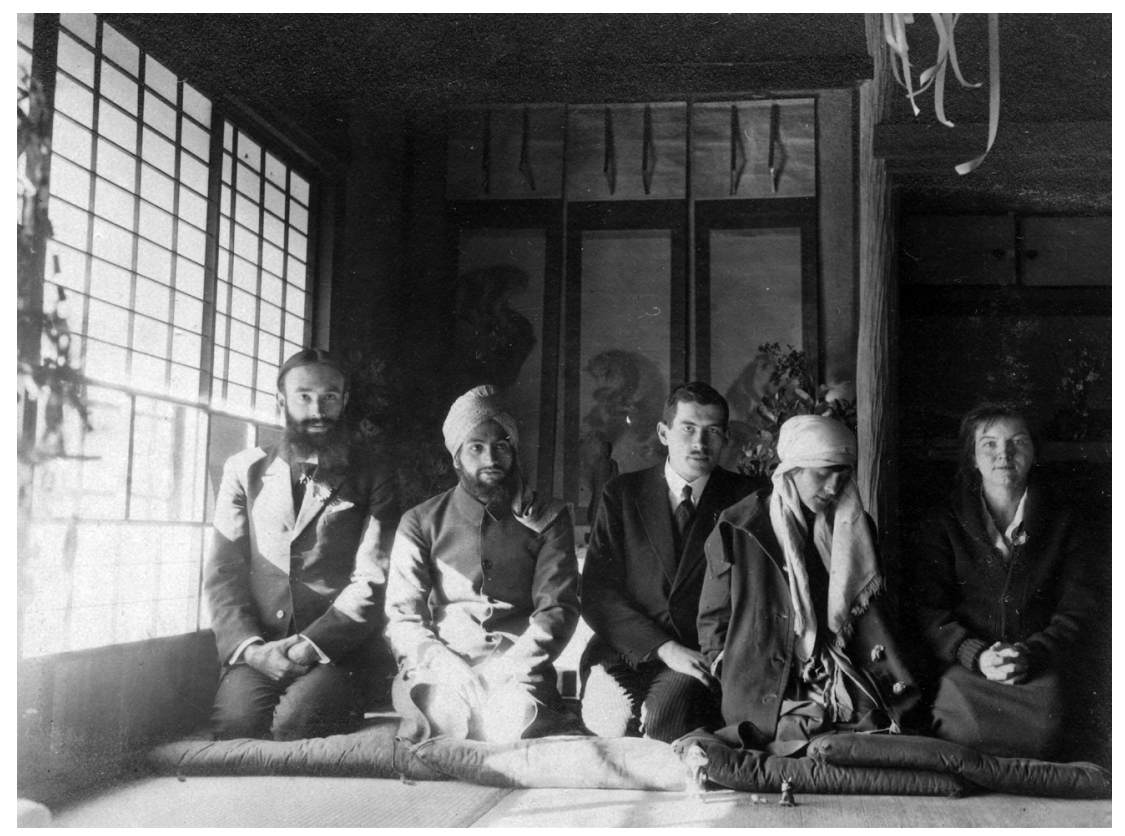

Fig. 5. Group photo, from the left: Philippe Barbier Saint Hilaire, Gurcharan Singh, the Lubieńskis and Noémi Raymond, undated (1924), private collection.

${ }^{34}$ Crafting a Modern World: The Architecture and Design of Antonin and Noémi Raymond, K.G.F. Helfrich, W. Whitaker (eds.), New York 2006, p. 16. 
It was through the TS network that the Raymonds were introduced to the life partner of Frank Lloyd Wright, Miriam Noël. Wright then became Antonín Raymond's teacher in his laboratory in Taliesin and later his employer. It was on the behest of Wright that the Raymonds initially travelled to Japan, with Antonín set to work on Wright's famous project, the Imperial Hotel. This move ultimately began what became their journey to establishing a famous architecture firm in Japan. While in Japan Noémi continued to act as a bridge between Antonín and the elite; her extensive network was key to many prestigious contacts and commissions.

\section{Garakutashū (en. "Circle for the Study of Odd Things and Junk")}

It was through Noémi that Antonín joined Garakutashū, a casual setting for open discussion, or to put it less glamorously an unfocused hodgepodge where self-styled intellectuals talked about their passion for collecting objects, their hobbies, and shared knowledge about Japanese arts such as woodblock printing, calligraphy, and ink painting. The group was led by an eccentric character named Mita Heibonji (Mita Rinzō). Heibonji, which means "temple of ordinary stuff" created a "temple," which he saw as a meeting place for intellectuals who were passionate about collecting, novelties, and ideas from abroad/outside Japan. Every initiate to the group received a name which included the word for "the temple" (ja. ji, o-tera), as if they were becoming a temple of a certain kind of "collecting." ${ }^{35}$ Heibonji founded the Garakutash $\bar{u}$ on 6 June 1919 and published the pamphlet Shumi to Heibon (en. "Hobbies and Ordinary Stuff") that was associated with it for twenty years until 1940.

The Shumi to Heibon journal was carefully printed with pages in colour and occasionally featured photographs from events and outings. It also featured short essays on collecting and notes on new ideas available in foreign literature. The discussions described in the group's pamphlets and magazines were at the core of its activity. Łubieński's cards depicting five initiations were printed in volume seventeen. The accompanying commentary by Heibonji explains his understanding of the drawings and encapsulates well the complexity of the work, but also the deeper connection and understanding that the members of Garakutash $\bar{u}$ shared. Heiboji writes:

The frontispieces of this book are designed by the Polish Count Lubienski. (They were used as designs for envelopes used in Monju Temple [nickname of one of the members] ceremony). My understanding of the images is as follows. I appreciated that Lubienski aims to express our group's innovative programme through this philosophical kind of artwork. Although we share a lack of mutual understanding through spoken language, as Lubienski doesn't have a sophisticated knowledge of Japanese and I don't speak foreign languages at all, I was able to see his deeper connection to our circle's purpose. This is even more moving because many Japanese people tend to see only the superficial part of our circle, and not the core of it. Some people are ashamed of being a part of it, or even create other meaningless imitation circles. With this being said, I am not sure if it is fortunate or not that only a man from a thousand miles away

${ }^{35}$ Ibidem, p. 17. 
truly understands our purpose. Now, let me explain each drawing. No. 1 Garakutashū Initiation: Mother of All Hobbies produced her adorable child, Garakutash $\bar{u}$. This child will start his journey to devote himself to the great true-hobby, and it will try to open his eyes and mind. Three masters welcome the child and take care of the child. From now on, they will try to raise this child to become the right hobbyist. No. 2 Education: The educators of the child attempt to teach him the true ways of hobby and Garakuta: with a hammer of effort, they broke the wall and built a temple of true hobby out of the broken pieces. The Ancestors provide the educators with a sword of creation and apocalypse, so that they can protect the child. No. 3 Light of Hope: The child awakens to notice that the world is full of light and power of hobby, however, he is still heteronomous. When the time comes, he will know that Hobby is ordinary, and he will open his mind to love for ordinary things. No. 4 Desire is Nirvana: The devotes of wrong hobbies become slaves, they suffer and end up crucified. Although extinct, they will be reborn in the land of new hobbies and feel happiness of rebirth. No. 5 Self-love: The child finally achieves enlightenment. ${ }^{36}$

This interpretation of Łubieński's drawings was in accordance with Garakutash $\bar{u}$ principles: smart, sharp and witty, with great deal of metaphor and irony. Considering the motifs Łubieński chose for his works of art, carpets etc., it is very likely that some of the "Polish cards" he was selling were quite similar to these five drawings for Garakuta. The series of five cards could be alternatively interpreted as illustrating a mystical path through life: 1. Birth, 2. Meeting a teacher - joy and discipline, 3. Mastery - (showing a likeness of the Chiron), the wise centaur, a mentor to Achilles and Asclepius, 4. Sacrifice, and 5. Eternal Return - the fight for a place of ultimate salvation inside the ouroboros that symbolises self-reflexivity or cyclicality, especially in the sense of something constantly re-creating itself, that is, the eternal return.

The discussions described in the circle's pamphlets and magazines were at the core of its activity. These covered a wide range of topics, predominantly questions of religion, philosophy and sexuality. It is unclear how closely this group was related to contemporary movements promoting esoteric spirituality which combined philosophy with spiritual or religious thought such as Theosophy, Spiritualism or Freemasonry. It is worth noting that the group encouraged international membership and was keen on including women. Furthermore, the proportion of foreign members who were involved in Theosophy and other networks created by foreigners in Japan was significant.

\section{Conclusion}

Joining the TS was important both to the Raymonds' future careers and to the Łubieńskis' stay in Japan. Through their TS friends the Raymonds were introduced to the art historian and curator of the Boston Museum of Art, Hervey Wetzel, who mediated their interest in Japanese art, as well as to ideas developed and promoted by Ernest Fenollosa and Kakuzō Okakura. Fenollosa and Okakura's belief that

${ }^{36}$ Five initiations - frontispieces by Count Lubieński, e.g. and Heibonji, About the Frontispices, "Shumi to Heibon," 1923, no. 17, pp. 16-18. 
a sophisticated new type of civilized man, the Japanese, who preserved the Asiatic ideals, and whose existence would culminate in a mystical union of Christ and Buddha in the silence of Nirvana glory where there was no more "East" and "West," had a great impact on the Raymonds and also, on the Lubieńskis.

By the late 1920s, however, this network gradually dissolved. The Raymonds became less involved and left for the US before the start of WWII. Stefan Łubieński returned to Poland and Saint Hilaire settled in India. Garakutash $\bar{u}$ meetings were no longer happening by 1940 . According to the surviving correspondence it is clear, however, that the friendship and spiritual connection of many of the members survived their geographical divide. Philippe remained a great friend to Stefan, sending him magazines from Pondicherry for years to come. Despite this fact, they parted spiritually, perhaps especially when Stefan fully embraced Anthroposophy again when back in Europe. In 1927 Lubieński published the book Between the East and the West - The mystical soul of Japan, which is structured as a contemporary perspective on Japan, its history and culture. The structure of the book is achronological and a historical overview of, for example Japanese religions, is combined with the reflection and comments of various contemporary contributors, such as Łubieński's note about the humanitarian, vegetarian and pacifist brotherhood established by Mushakoji. In the conclusion he reinforces that the East and the West need to exist in equilibrium. It may be said that the tension between learning about and participating in local practices related to spirituality and being a representative of another culture, felt to be as equally important and necessary and thus experiencing an urgency to share it, permeates the book.

The TS network in 1920s Japan can be viewed as an efficient and fruitful collaboration of people who aimed to find and connect with what Okakura called "the ideal of the great sophisticated Asian man." According to all available accounts discussed above, Stefan Łubieński was an artist talented in many areas: musician and trained composer, he was also a passionate painter and designer. He illustrated his own writings and mystery dramas and also produced both paintings and tapestries. Some of these works possess a strong Japanese quality. Stefan Łubieński returned to Poland in 1925, and soon afterwards became its diplomatic representative to Holland and France, where he bravely supported the Polish resistance. Despite his government position, he did not identify with the growing power of the Communist regime in post-war Poland and chose to spend the remainder of his life in Holland, the country of his beloved second wife, Nora. He never became respected as an Anthroposophical artist, and deeply regretted that because of his extended stay in Japan he had never met Rudolf Steiner in person. Nonetheless, he embarked on his own inventive quest to explore and write about humanity and existence. This article is intended to introduce Stefan Łubieński and his colourful and inspiring stay in Japan to a wider academic audience. Furthermore, it aimed not only to discuss and elaborate on Łubieński's motives to travel to the East, but also to explore the impact the stay had on Łubieński and his network. A method which foregrounds the importance of thinking through a lens highlighting transnational network enables us to recognize Lubieński as a part of the TS and Garakutashū networks as well as to further examine 
his other connections with the Hanis and Jiyū Gakuen, the Shiseidō Gallery in Tokyo and Hoshi Hajime's pharmaceutical empire. Indeed, the story of Stefan Łubieński confirms that Theosophy and the TS became here, again, in Sixten Ringbom's words, a significant "connecting link." ${ }^{37}$

\section{References}

Algeo A.S., Beatrice Lane Suzuki and Theosophy in Japan, "Theosophical History” 2005, vol. 11, no. 3, pp. 3-16.

Crafting a Modern World: The Architecture and Design of Antonin and Noémi Raymond, Helfrich K.G.F, Whitaker, W. (eds.), New York 2006.

Jiyū Gakuen no Rekishi 1 Zōshigaya jidai (en. "History of Jiyū Gakuen 1 Zōshigaya period"), Tokyo 1985.

Jennings J.M., The Opium Empire: Japanese Imperialism and Drug Trafficking in Asia, 1895 1945, Westport, CT 1997.

Kapnist I. What Can Be Done to Save Russia Quickly? “The Sun” June 30, 1918, http://chroniclingamerica.loc.gov/lccn/sn83030431/1918-06-30/ed-1/seq-47/ [access: 22.02.2017].

Łubieński S., Five initiations - frontispieces by Count Lubienski, np. and Heibonji, About the Frontispices, "Shumi to Heibon" 1923, no. 17, pp. 16-18.

Łubieński S., Między Wschodem a Zachodem: Japonja na straży Azji. Dusza mistyczna Nipponu, etc. (en. "Between East and West, Japan as a Guard of Asia, Mystical Spirit of Japan, etc."), Warszawa 1927.

Łubieński S., Vor der Schwelle, Lebenserzählung eines polnischen Künstlers und Suchers (en. "Before the Threshold; Life story of one Polish Artist and Seeker"), Driebergen 1974.

Łubieński S., Teernstra-Łubieński M., Wegen naar geestelijk inzicht: het IK tussen microkosmos en macrokosmos (en. "Ways to Spiritual Light, Man between Microcosm and Macrocosm"), Deventer 1984.

Ringbom S., The Sounding Cosmos: A Study in the Spiritualism of Kandinsky and the Genesis of Abstract Painting, Åbo 1970.

Sagara Ch., Tuesday Visitors, "Fujin no Tomo" 1923, vol.7, no 1, pp. 91-93.

Saint Hilaire P.B., Itinéraire d'un enfant du siècle: correspondance de Pavitra avec son père: 1918-1954: de l'École polytechnique à l'ashram de Sri Aurobindo, de Paris à Pondichéry via le Japon et la Mongolie-Intérieure, Paris 2001.

Shiseidō Gyararī shichijūgonenshi: 1919-1994, H. Tomiyama (ed.), Tōkyō 1995.

Wright F.L., An Autobiography, Petaluma 2005.

${ }^{37}$ S. Ringbom, The Sounding Cosmos: A Study in the Spiritualism of Kandinsky and the Genesis of Abstract Painting, Åbo 1970. The author would like to thank Łubieński family, namely Mrs Adola McWilliam, one of the founders of Stefan Lubieński foundation, Cecile van Spronsen, Prof Koichi Kuyama, who kindly provided me with materials about Stefan Lubieński and Asadori Kato and Jiyū Gakuen archivist Ms Tami Murakami for their ongoing support. 